\title{
Greek tragedy moves on one act
}

Quite why Dr David Baltimore, now president of the Rockefeller University, should so vigorously have defended a disputed 1986 paper of which he was a co-author has never been self-evident. Now the paper has been retracted.

THE long-running dispute over Dr David Baltimore's involvement with a research article on the use of the transgenic mouse in the study of the genes of the human immune system seemed, two years ago, to have all the makings of a Greek tragedy (Nature 333, $795 ; 1988)$. And so, now, it has emerged. In Euripides, the moving tragedies are those in which a concatenation of misfortune is needlessly threaded through the patterns of people's lives not by intractable external circumstances, but because of the implacable influence of some person's human failing, pride perhaps.

The circumstances of this case are nevertheless both memorable and significant (see page 262), and will cast a long shadow over the conduct and even the reputation of research, not least because of Baltimore's high personal reputation and the respect which that commands. Baltimore was still only 32 when, in 1970, he announced (independently of but simultaneously with Dr Howard Temin) the discovery of reverse transcriptase, the enzyme that converts genetic information embodied in an RNA sequence into an equivalent sequence of DNA (Nature 226, 1,209; 1970). It was inevitable that, in 1975, Baltimore and Temin (and Dulbecco) should have shared the Nobel Prize for Physiology and Medicine.

Baltimore's achievements since then have been remarkable, both as a scientist and administratively. Among many other things, he was among the first to recognize the importance of transgenic mice, animals grown from embryos into which foreign genes have been transplanted, as a means of studying the functions of human genes. The transgenic mice used in the disputed and now retracted article (Weaver, D. et al. Cell45, 247; 1986) came from a line founded two years earlier byWeaver(atColumbiaUniversity)andBaltimore.

Baltimore's influence as an administrator has also been considerable. For the past decade (since 1982), he has been best known as the first director of the Whitehead Institute at the Massachusetts Institute of Technology (MIT), the institution endowed with a benefaction of more than $\$ 100$ million of 1980 money derived from the sale of the cosmetics company Revlon. There are many who believe that the endowment would not have been made had Baltimore not been available as the founding director.

Baltimore has never been a powerbroker in the most familiar US pattern, which entails commuting to Washington to run powerful committees, but he was the co-chairman (with Samuel O. Thier, president of the US Institute of Medicine), of the important (and liberal) report (in 1984) on the AIDS epidemic. It was only natural that, last year, he should have become the president of the Rockefeller Intitute in New York, where he had been a PhD student from 1960 to 1964 .

There is no reason why a single retracted article should interrupt these plans, but the protracted antecedents of the affair will cast a cloud on them. The case is amply documented. The first whistleblower was $\mathrm{Dr}$ Margot O'Toole, an untenured researcher in Dr Thereza Imanishi-Kari's laboratory, who alleged that she had been unable to repeat measurements reported in the disputed paper and that she had subsequently been unable to verify that the data published had actually been obtained in the laboratory.

O'Toole appears first to have taken her complaints to Baltimore, which may be considered to have been a proper course of action. Baltimore has said that he heard her out courteously, explaining why she was mistaken. O'Toole's account is that he dismissed her version of events peremptorily. Those who know Baltimore's emphatic way of making a case he believes to be correct will readily acknowledge that the two accounts can be reconciled. O'Toole's complaints were investigated internally at MIT and by a panel appointed by Tufts University, resulting in opinions matching that of Baltimore.

Part of the damage done by the affair is that suffered by O'Toole, whose temporary employment was terminated by Dr ImanishiKari. (After an interval of some three years, O'Toole is now employed at the Genetics Institute, the Boston-based biotechnology company.) It appears, nevertheless, that the only respect in which her conduct can be criticized is that she took with her 17 photocopied pages of Imanishi-Kari's laboratory notebook, and turned them over to $\mathrm{Mr} \mathrm{Wal}$ ter Stewart and Dr Ned Feder, the two $\mathrm{Na}$ tional Institutes of Health (NIH) researchers with a reputation for conducting zealous investigations of impropriety in research.

Baltimore was well within his rights in scorning the request from Feder and Stewart for access to the experimental data, but the haughtiness of his rejection of it may have helped to precipitate the NIH investigation that followed. It may be of some interest that, in 1987 and 1988, Nature declined to publish two versions of a manuscript in which Feder and Stewart spelt out what they considered to be errors in the published paper, partly because it then seemed probable that the matter would be properly investigated. In retrospect, their arguments are more appealing than they may then have seemed.

Baltimore has often spoken as if he believed that Feder and Stewart had a personal animus against him, and as if that were generously reciprocated, especially against Stewart, about whom he has been colourfully eloquent, as only one who is convinced that he must be right can be. In the event, Stewart was seconded by NIH to the congressional Dingell committee, which announced its intention to investigate the disputed paper.

Why did Baltimore feel so strongly? On the face of things, there was no reason why he should have been so concerned. While Imanishi-Kari's study was potentially interesting, in that it showed that artificially introduced human transgenes could determine the idiotype of the immunoglobin molecules produced by transgenic mice, many of those working in the field were at the time persuaded that the results, although suggestive, would require further investigation (which is not an unusual circumstance). Baltimore himself acknowledged that he did not follow Imanishi-Kari's view that the data provide support for Jerne's network theory, but that the data rather than their interpretation were his sole concern.

It would have been entirely possible, but also legitimate, for Baltimore to have been much more detached from the affair. He had arranged for the transgenic mice, and had helped to plan and write up the study, but the experimental data had been gathered in Imanishi-Kari's laboratory. Why take the risk of vouching for their accuracy? Some of Baltimore's friends (this one in particular) urged him to make some kind of public statement shedding full personal responsibility for the study. But they revealed an angrily defensive person, most offended that work with which he had been associated should be challenged.

Baltimore is by no means the first, and will almost certainly not be the last, distinguished researcher to be taken in by the errors (now alleged to be falsifications) of a close colleague. His defence of himself and ImanishiKari had been conducted with aplomb, resting on the basis that scientific freedom is threatened by an excess of zealous inquiry from persons outside the community and from the Congress. Especially memorable are his "Dear colleague..." letter, widely circulated in 1988, and his indignant riposte to Congressman John Dingell at the end of the public hearings on the subject in 1989.

John Maddox 